\title{
MULTIMEDIA LEARNING FOR WUDHU AND SHOLAT PROCEDURES ANDROID BASED AT TK PERTIWI 01 SERANG
}

\author{
Widiastuti1; Siti Masturoh² ; Ahmad Hafidzul Kahfi ${ }^{3}$; M Rangga Ramadhan Saelan ${ }^{4}$; Ridan Nurfalah ${ }^{5}$; \\ Muhammad Hilman Fakhriza ${ }^{6}$ \\ ${ }^{1}$ Computer Science; ${ }^{2,3,4,5}$ Information System; ${ }^{6}$ Technical Information; \\ 1,2,3,4,5,6 STMIK Nusa Mandiri, Jakarta, Indonesia \\ $1,2,3,4,5,6$ www.nusamandiri.ac.id \\ widiastuti.wtu@nusamandiri.ac.id ${ }^{1}$; siti.uro@nusamandiri.ac.id ${ }^{2}$; ahmad.azx@nusamandiri.ac.id ${ }^{3}$; \\ rangga.mgg@nusamandiri.ac.id ${ }^{4}$; ridan.rlh@nusamandiri.ac.id5; hilman.mhz@nusamandiri.ac.id6
}

\begin{abstract}
Wudhu is one way to purify oneself from uncleanness and suffering. Performing ablution perfectly in accordance with Islamic Shari'a is the key to receiving prayer. The introduction of religious activities such as ablution and prayer from an early age is considered necessary. Learning ablution and prayer is usually done by parents repeatedly and by example. In one study, 8 out of 10 children aged 5-6 years did not recognize ablution when they were praying. The method of developing multimedia systems by Luther-Sutopo is one of the system development methods used by multimedia application developers. Therefore it will be built an Android operating learning media that uses Adobe Flash technology to display an animated image, motion, and audio in a 2-dimensional form. This learning media will display 2-dimensional objects of ablution movements, namely intentions, washing both feet and prayer after ablution, and prayer movements from beginning to end and added a few daily prayers. The results of this study are in the form of learning applications for ablution and fivetime prayer based on Android. In this application using elements of text, images, animations, and sounds to attract and make it easier for children to remember lessons on how to perform ablution and prayer and various kinds of daily prayers.
\end{abstract}

Keywords: Multimedia Learning, Wudhu, Sholat

Abstrak-Wudhu adalah salah satu cara untuk menyucikan diri dari kenajisan dan penderitaan. Melakukan wudhu dengan sempurna sesuai dengan syari'at Islam adalah kunci untuk menerima doa. Pengenalan kegiatan keagamaan seperti wudhu dan doa sejak usia dini dianggap perlu. Belajar wudhu dan doa biasanya dilakukan oleh orang tua berulang kali dan dengan contoh. Dalam satu penelitian, 8 dari 10 anak berusia 5-6 tahun tidak mengenali wudhu ketika mereka berdoa. Metode pengembangan sistem multimedia oleh Luther-Sutopo adalah salah satu metode pengembangan sistem yang digunakan oleh pengembang aplikasi multimedia. Oleh karena itu akan dibangun media pembelajaran operasi Android yang menggunakan teknologi Adobe Flash untuk menampilkan gambar animasi, gerak dan audio dalam bentuk 2 dimensi. Media pembelajaran ini akan menampilkan objek 2 dimensi gerakan wudhu, yaitu niat, membasuh kedua kaki dan doa setelah wudhu, dan gerakan doa dari awal hingga akhir dan menambahkan beberapa doa harian. Hasil penelitian ini berupa aplikasi pembelajaran wudhu dan sholat lima waktu berbasis Android. Dalam aplikasi ini menggunakan elemen teks, gambar, animasi dan suara untuk menarik dan membuatnya lebih mudah bagi anak-anak untuk mengingat pelajaran tentang cara melakukan wudhu dan doa dan berbagai jenis doa sehari-hari.

\section{Kata Kunci: Multimedia Pembelajaran, Wudhu, Sholat}

\section{INTRODUCTION}

Early childhood education is very important for every child where the early stages of the brain develop very rapidly, in terms of the time of learning at this time must continue to be developed following the times. It is no stranger that children in the modern era are now familiar with a variety of sophisticated media, one of which is Gadgets and therefore the role of parents in supervising children in playing and learning is very important. Problems that have been complained of by students' parents are bored children in learning (Masganti, 2015), cranky child when studying and out of focus (Suseno, 2010), can't spell the words yet (Pratiwi \& Ariawan, 2017) children will often forget the time when they were engrossed in playing gadgets (Chusna, 2017).

Early childhood education is a coaching effort aimed at children from birth until the age of six carried out by providing educational stimuli to help physical and spiritual growth so that children have readiness to enter more education (Sekretaris 
Negara Republik Indonesia, 2003). One of the things that can support the absorption of a child's brain is through education, but these days many of children cannot read well (Septian et al., 2017) then with this learning system children must be accompanied by teaching staff or teachers, parents, dictionary books and children must read well.

It is time for parents to be selective in choosing learning materials and children's games to match what the child should be learning. Therefore this application can support parents and teachers in giving lessons to children where children can learn without they feel they are learning.

The method used in software development is the Multimedia Development Life Cycle Method which consists of 6 stages: concept, design, material collecting, assembly, testing and distribution.

From the description above, the authors conclude that the purpose of making this program is as a supporting medium for early childhood learning in learning the procedures for ablution and prayer. Where this application can be used interactively by them anytime and anywhere.

\section{MATERIAL AND MODELS}

\section{A. Data Collection Technique}

1. Observation

Direct observation of the learning and teaching process at TK Pertiwi 01 Serang was carried out.

2. Interview

The authors conducted interviews directly to the principal, teachers, and parents of guardians of students found in the school.

3. Questioner

The author conducted direct socialization and distributed questionnaires to the teacher and parents of students.

\section{B. System Development Model}

Software development model for making the application using Multimedia Development Life Cycle Method Luther-Sutopo Version (Nurajizah, 2016) that consists 6 steps concept: design, material collecting, assembly, testing and distribution.

The stages of Multimedia Development (Binanto, 2010) are as follows:

a. Concept

The concept phase of the section to get the initial concepts and ideas for the development of multimedia-based applications, firstly collect data related to the process of building multimedia products. b. Design

At the Design stage the stage of making specifications regarding the program architecture, style, appearance and material requirements for the program. The specifications are made as detailed as possible so that in the next stage, namely collecting and assembly materials, new decision making is no longer needed, just use the decisions that have been determined at this stage. However, in practice project work in the initial stages will often experience material additions or reductions in the application part or other changes.

c. Material Collecting

The material collection stage is in accordance with the needs worked on. These materials include clip art images, photos, animations, videos, audio, etc. which can be obtained free of charge or by ordering to other parties according to the design. This stage can be done in parallel with the assembly stage.

Material collecting is the stage where the collection of materials according to needs is done (Septian et al., 2017).

d. Assembly

The stage of making all objects or multimedia material. Making an application is based on the design stage, such as storyboards, flowcharts and / or navigation structures.

Assembly is the stage of making of materials that have been collected based on the design that has been prepared at the design stage, which is based on the storyboard and navigation structure (Rahman \& Tresnawati, 2016)

e. Testing

The testing phase is done after completing the assembly phase by running the application or program and see whether there are errors or not. The first step in this stage is called the testing phase.

f. Distribution

This stage is the last stage of the multimedia development cycle. Distribution can be done after the application is declared to be suitable for use. At this stage, the application will be stored in a storage medium such as CDs, mobile devices or website.

\section{RESULTS AND DISCUSSION}

\section{a. Concept}

At this stage the author collects some learning media references that will be used as an illustration of concepts that will be made such as pictures, backsounds, until the learning materials that are expected to be suitable for early childhood 
and design some scene menus as reference layers to be made from the initial appearance to completion. Below is picture 1. the draft concept of the program to be made:

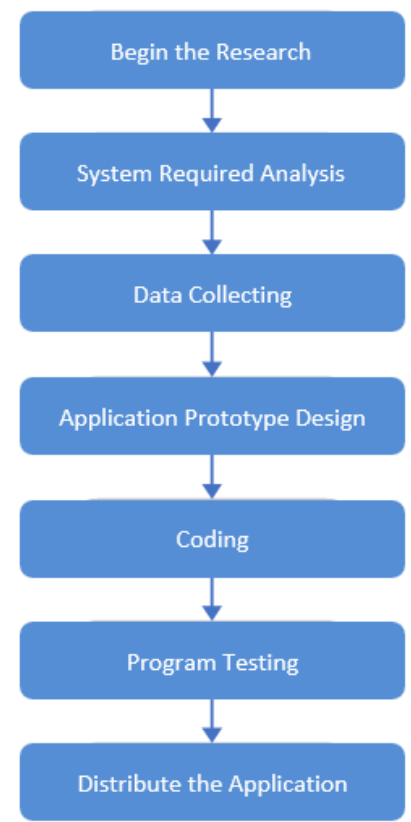

Source: (Widiastuti et al., 2020)

Picture 1 Draft Concept

b. Design

From the concept above has drawn a scene menu or sequence menu layer, then the contents of the scene menu are then made as the program storyboard in table 1 below:

Tabel 1. Storyboard Scene of Application Menu

Scene1 Scene of the initial layout of the Opening page contains Loading leading to the main menu page.

Scene2 Scene of main menu page, which contains the application menu display options Destination, Material, Evaluation, Profile and exit

Scene3 Scene of material page. It contains a display of menu: ablution (wudhu), moslem prayer (sholat), daily prayers (do'a)

Scene4 Scene of purpose page, contains a description of the purpose of learning media

Scene5 Scene Prayer page, to display daily prayers

Scene6 Scene of Ablution (Wudhu) page, to display ablution procedures

Scene7 Scene of moslem prayer (sholat) page, contains the procedurs and material of moslem prayer(sholat).

Scene8 Scene of Evaluation page, consists multiple choice questions.

Scene9 Scene of Profile page, consists developer profile.

Source : (Widiastuti et al., 2020)

\section{User Interface}

The user interface design of the application is based on the Storyboard in table 1. Following is the App Display Menu:

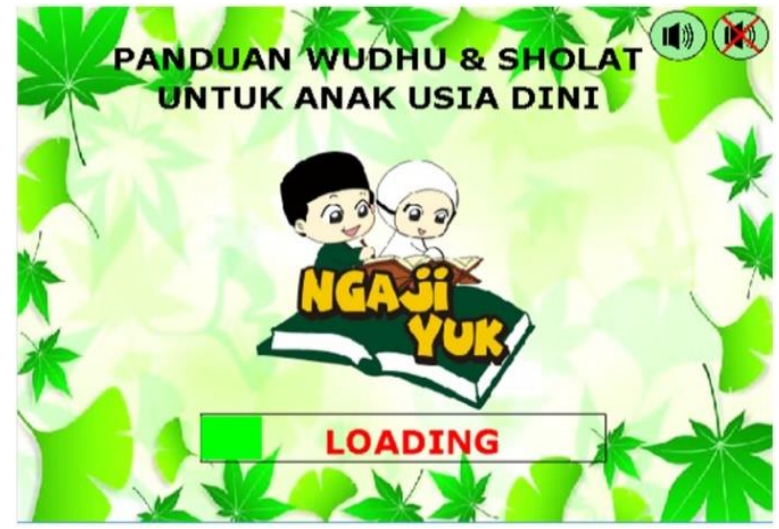

Source : (Widiastuti et al., 2020)

Picture 2 Scene of App Display Menu

From the display Picture 2. Scene of App Display Menu above is scene 1 which is the opening page display Loading to the main menu.

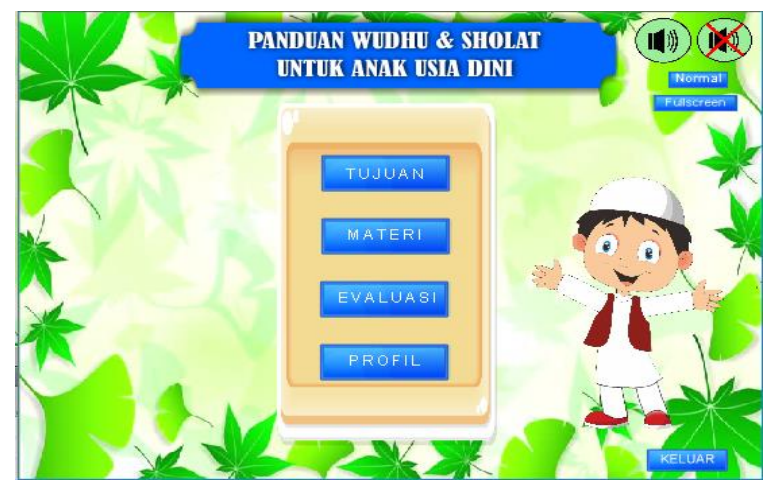

Source : (Widiastuti et al., 2020)

Picture 3 Main Display Menu

Picture 3. the main display menu above is the scene menu 2 which contains the purpose (tujuan) menu button, material (materi), evaluation (evaluasi), profile (profil) and exit.

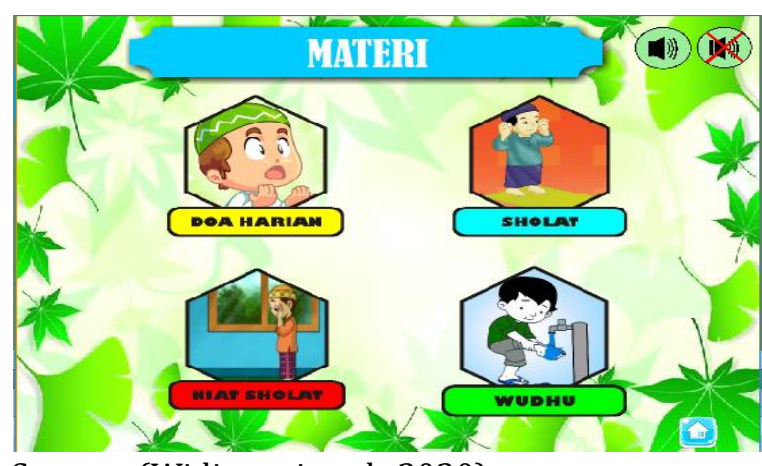

Source : (Widiastuti et al., 2020)

Picture 4. Material Menu 
Picture 4. The material menu above is a scene menu 3 which contains core learning menus such as Daily Prayers (Doa Harian), Moslem Prayer (Sholat), Ablution, Intention to Pray.

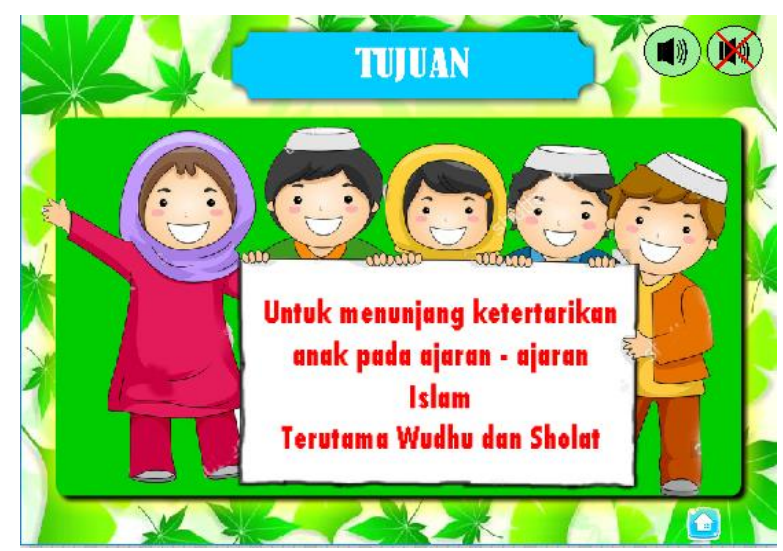

Source : (Widiastuti et al., 2020)

Picture 5. Material Display Menu

From Picture 5. material display menu above is seen from the menu menu 4 which has a description of the purpose for which the application was made.

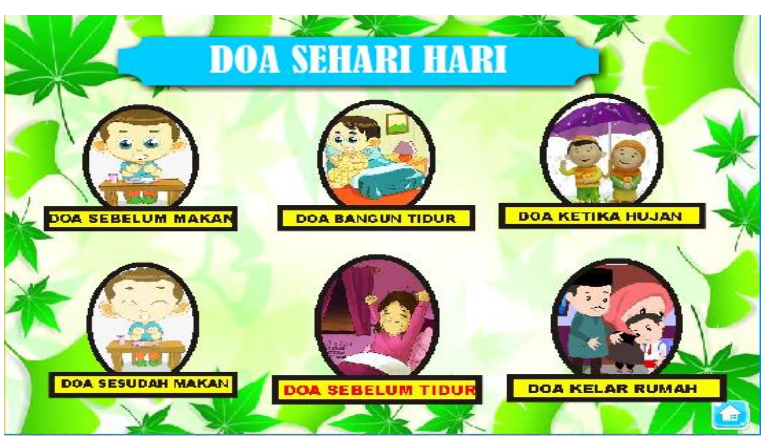

Source : (Widiastuti et al., 2020)

Picture 6 Daily Prayer Display Menu

In picture 6 Prayer display menu above is a Picture of the scene menu 5 which contains a daily Prayer menu.

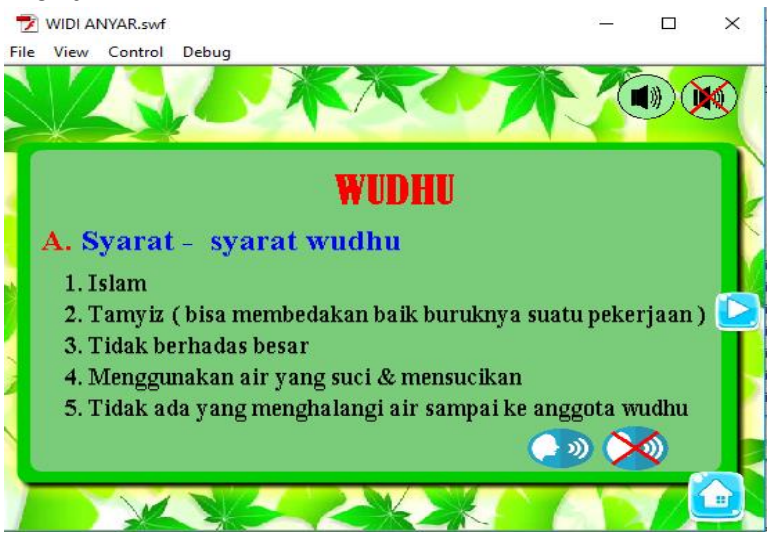

Source : (Widiastuti et al., 2020)

Picture 7. Ablution Display Menu
In picture 7. Ablution material display above is a sample display of ablution that contains a description of ablution material in addition to decomposing ablution material there is also a sound that can explain the material so that children can understand specifically for children who cannot read fluently.

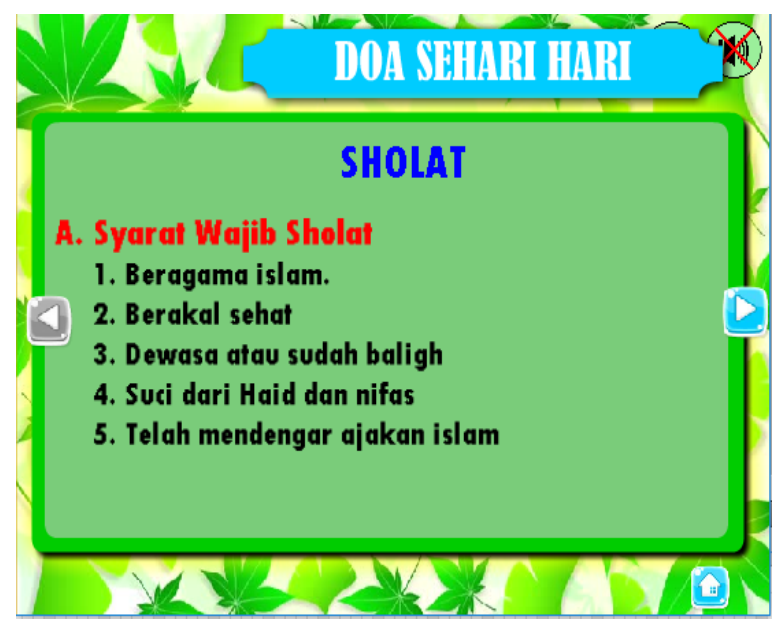

Source : (Widiastuti et al., 2020)

Picture 8 Prayer (sholat) Display Menu

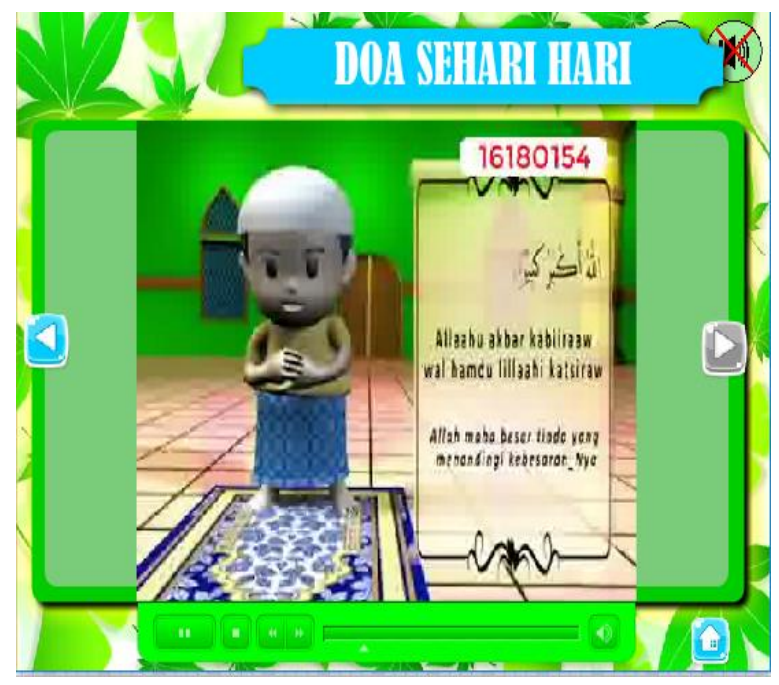

Source : (Widiastuti et al., 2020)

Picture 9 Prayer Learning Video

In Picture 8 and 9 above is the implementation of the 7 scene menu on this menu taken a picture of the prayer material and the prayer video tutorial. With the prayer material it is expected that children can understand how important prayer is, in addition to writing and video for each layer there is also a voice that explains the writing above in order to facilitate children who cannot read. 


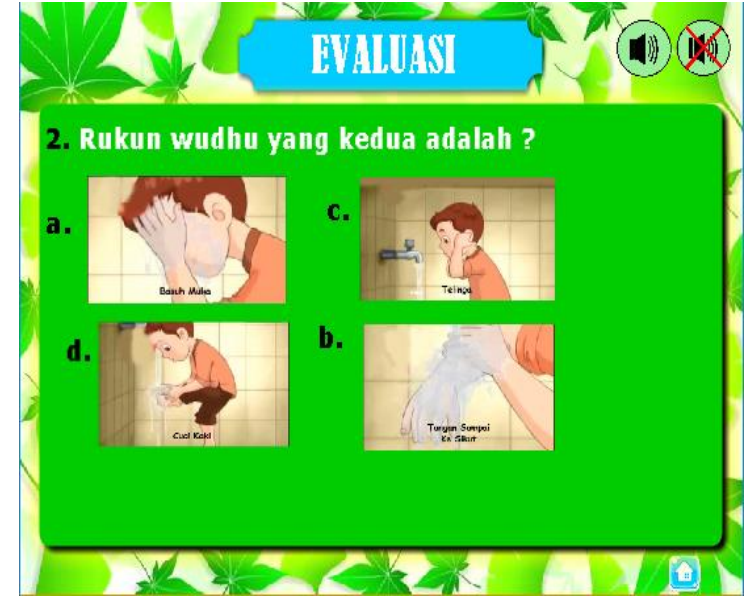

Source : (Widiastuti et al., 2020)

Picture 10 Scene of Evaluation Display Menu
Picture 10 above is a form of implementation of scene 8 in the form of evaluating prayer learning that decomposes in the form of multiple choice. In this evaluation menu children can hone the knowledge they have learned by using this material.

\section{c. Material Collecting}

1. Picture

Making this application program requires a lot of reference display is needed, in this view the author makes and obtains from various sources Picture, the following table 2 collecting materials used in the program:

Tabel 2. Collecting Material Used

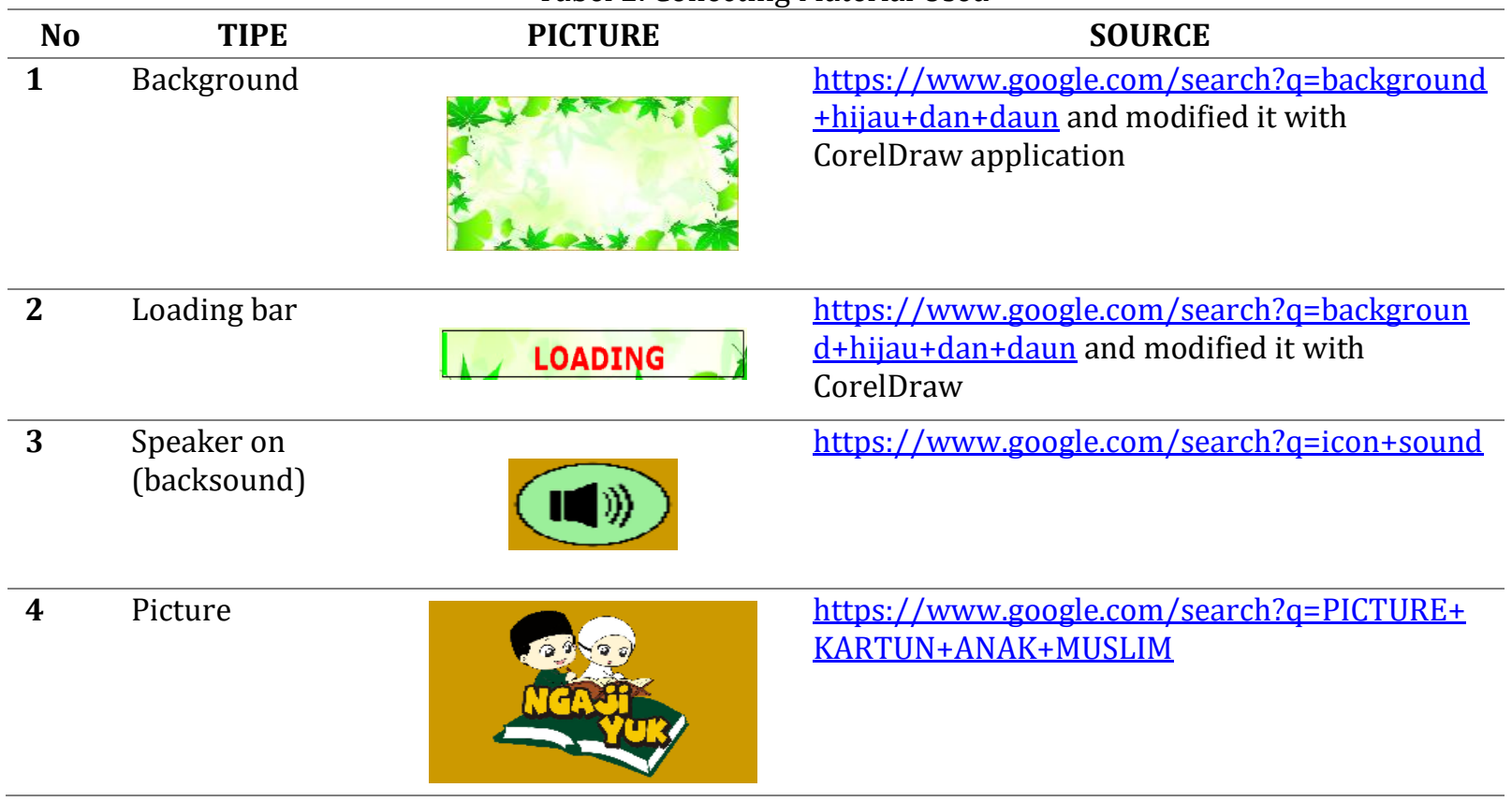

Source : (Widiastuti et al., 2020)

2. Audio

Audio was required in making this application. It supports learning because this application not only uses text in the explanation of the material but also uses supporting audio, as a medium of explanation for children who cannot read well so that learning can be conveyed. The following table 3 Audio sources used:

Tabel 3. Audio Source Used:

\begin{tabular}{llll}
\hline No & Jenis & Audio & Sumber \\
\hline 1 & MP3 & Back- & $\underline{\text { https://www.google.co }}$ \\
& & sound & $\underline{\text { m/search?q=backsoun }}$ \\
& & & $\underline{\mathrm{d}+\text { Aplikasi+Anak }}$ \\
\hline
\end{tabular}

\begin{tabular}{llll}
\hline No & Jenis & Audio & Sumber \\
\hline 2 & MP3 & $\begin{array}{l}\text { Intenti } \\
\text { on to } \\
\text { Pray }\end{array}$ & Recorded \\
\hline 3 & MP3 & $\begin{array}{l}\text { Qunut } \\
\text { Prayer }\end{array}$ & Recorded \\
\hline 4 & MP3 & $\begin{array}{l}\text { Ablutio } \\
\text { n }\end{array}$ & Recorded \\
& & Prayer \\
\hline
\end{tabular}

Sumber: (Widiastuti et al., 2020)

d. Assembly

At this stage the authors make the design of an application work program in the form of a menu 
contained in the program. The draft program flow that has been designed using the navigation structure can be seen in Figure 11 as follows:

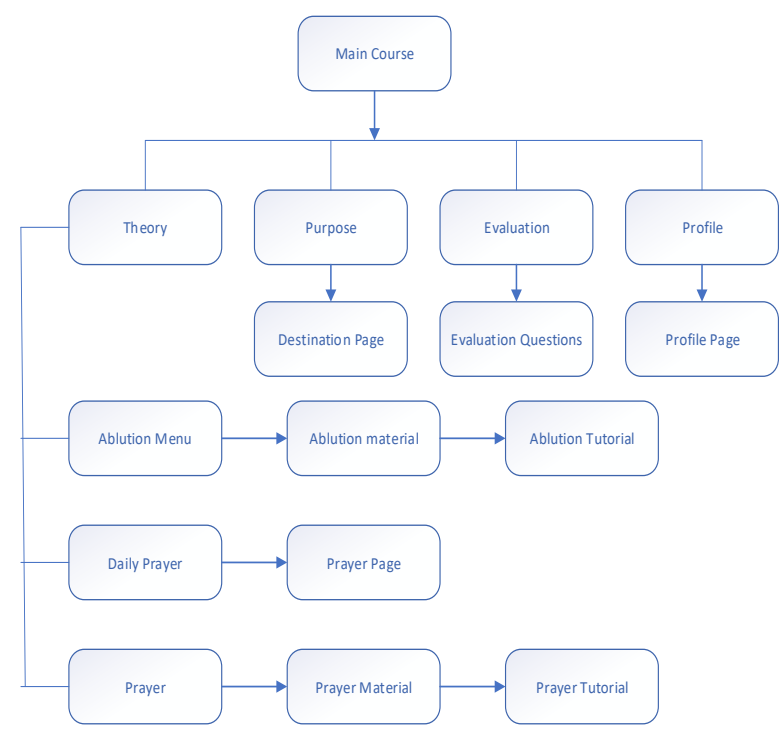

Source : (Widiastuti et al., 2020)

\section{Picture 11. Application Navigation Structure}

From picture 11. Navigation structure, we can see the flow of the design program that has been compiled at the design stage clearly from the Main Menu page to the program content section.

\section{e. Testing}

Learning media that have been made, then tested through software testing including Black box testing. Following in table 4 testing:

Tabel 4. Black Box Testing:

\begin{tabular}{llll}
\hline Input & Process & Output & Result \\
\hline Home Button & on & To display the main menu & Corresponded \\
& (release)\{_root.gotoAndStop("menu");\} & &
\end{tabular}

\begin{tabular}{|c|c|c|c|}
\hline Start Button & on (release)\{gotoAndStop(" ");\} & To display the start process & Corresponded \\
\hline $\begin{array}{l}\text { Previous } \\
\text { Button }\end{array}$ & on (release) $\{$ prevFrame ()$:\}$ & $\begin{array}{l}\text { To return to the previous } \\
\text { scene }\end{array}$ & Corresponded \\
\hline $\begin{array}{l}\text { Continou } \\
\text { Button }\end{array}$ & on (release) $\{$ nextFrame $0 ;\}$ & To proceed to the next scene & Corresponded \\
\hline $\begin{array}{l}\text { Evaluation } \\
\text { Button }\end{array}$ & $\begin{array}{l}\text { on(release)\{gotoAndStop("profil");\}on } \\
\text { (release)\{gotoAndStop("quiz");\} }\end{array}$ & To open Evaluation & Corresponded \\
\hline $\begin{array}{l}\text { Button Back } \\
\text { Sound }\end{array}$ & $\begin{array}{l}\text { stop } 0 \text {; } \\
\text { this.createEmptyMovieClip("s2",4); } \\
\text { backsound1 = new Sound(s2); } \\
\text { backsound1.attachSound("musik"); } \\
\text { backsound1.start(0,9999); } \\
\text { backsound1.setVolume(100); }\end{array}$ & $\begin{array}{l}\text { To turn off or turn on } \\
\text { backsound in the application. }\end{array}$ & Corresponded \\
\hline
\end{tabular}

Source : (Widiastuti et al., 2020)

\section{f. Distribution}

Many users can use Multimedia learning education ablution and prayer procedures, it is necessary to distribute the application. The purpose of distributing this application in addition to distributing applications through the network is also to be able to become an evaluation so that it will be able to develop a better system. Distribution of this application is done by uploading *.apk files to online storage media such as dropbox, mediafire and others. In the future, this game will also be uploaded to Google Play Store if the application has been made absolutely no changes and does not have bugs or other deficiencies. From the results of the distribution that has been done the authors conducted an evaluation leaflet in the form of a questionnaire to parents of guardians of students who use this 
application. The results of the questionnaire obtained 97\% answered Yes and 3\% answered No.

\section{CONCLUSION}

After the authors analyze the results of the application distribution questionnaire, the writer can conclude that this application can help early childhood learning, they become interested in learning ablution, obligatory Muslim prayers (sholat) and memorizing daily prayers, their learning system becomes fun, it can be concluded that this learning method is very useful because it can facilitate children in understanding and digesting learning and practicing it. Besides this application can be used anywhere, anytime and easy to use. Hope big writer with this application can be a motivation for teachers in schools to always innovate in delivering learning material.

\section{REFERENCE}

Binanto, I. (2010). Multimedia Digital - Dasar Teori dan Pengembangannya. Penerbit Andi.

Chusna, P. A. (2017). Pengaruh Media Gadget Pada Perkembangan Karakter Anak. Dinamika Penelitian: Media Komunikasi Penelitian Sosial Keagamaan, 17(2), 315-330. http://103.106.116.16/index.php/dinamika/ article/view/842

Masganti, S. (2015). Psikologi perkembangan anak usia dini. Perdana Publshing.

Nurajizah, S. (2016). Multimedia Development Life Cycle Pada Aplikasi Pengenalan Lagu Anak Anak Berbasis Multimedia. PROSISKO: Jurnal Pengembangan Riset Dan Observasi Sistem Komputer, 3(2), 14-19. http://ejurnal.lppmunsera.org/index.php/PROSISKO /article/view/18

Pratiwi, I. M., \& Ariawan, V. A. N. (2017). Analisis kesulitan siswa dalam membaca permulaan di kelas satu sekolah dasar. Sekolah Dasar:Kajian Teori Dan Praktik Pendidikan, 26(1), 69-76. http://journal2.um.ac.id/index.php/sd/articl e/view/1332

Rahman, R. A., \& Tresnawati, D. (2016). Pengembangan Game Edukasi Pengenalan Nama Hewan Dan Habitatnya Dalam 3 Bahasa Sebagai Media Pembelajaran Berbasis Multimedia. Jurnal Algoritma, 13(1), 184-
190.

http://www.jurnal.sttgarut.ac.id/index.php/ algoritma/article/view/323

Sekretaris Negara Republik Indonesia. (2003). UNDANG-UNDANG REPUBLIK INDONESIA NOMOR 20 TAHUN 2003 TENTANG SISTEM PENDIDIKAN NASIONAL. http://kelembagaan.ristekdikti.go.id/wpcontent/uploads/2016/08/UU_no_20_th_200 3.pdf

Septian, H., Hidayat, E. W., \& Rahmatulloh, A. (2017). Aplikasi Pengenalan Bahasa Arab dan Inggris untuk Anak-Anak Berbasis Android. 2(2), 71-78. https://doi.org/10.15575/join.v2i2.100

Suseno, D. D. (2010). Hubungan Antara Pola Asuh Orang Tua Dengan Kemandirian Anak Usia Prasekolah Di TK Aisyiyah Mendungan Sukoharjo [Universitas Muhammadiyah Surakarta.]. In Universitas Muhammadiyah Surakarta.

http://eprints.ums.ac.id/id/eprint/10439

Widiastuti, W., Masturoh, S., Kahfi, A. H., Saelan, M. R. R., Nurfalah, R., \& Fakhriza, M. H. (2020). Final Report Independent Research: Learning Multimedia Procedures for Wudhu and Sholat Android Based on TK Pertiwi 01 Serang. 
P-ISSN: 1978-2136 | E-ISSN: 2527-676X | Multimedia Learning For Wudhu ...

Techno Nusa Mandiri : Journal of Computing and Information Technology

As an Accredited Journal Rank 4 based on S Dirjen Risbang SK Nomor 21/E/KPT/2018 